\title{
Spawning strategies in cypriniform fishes in a lowland river invaded by non-indigenous European barbel Barbus barbus
}

\author{
Catherine Gutmann Roberts $(\mathbb{D} \cdot$ J. Robert Britton
}

Received: 15 May 2020/Revised: 11 August 2020/Accepted: 23 August 2020/Published online: 4 September 2020

(C) The Author(s) 2020

\begin{abstract}
Spawning strategies of lowland river fishes include single spawning, where reproduction generally occurs in early spring to provide $0+$ fish with an extended growth season through the summer, but with a high risk of stochastic mortality events occurring, such as early summer floods. This risk can be reduced by multiple or protracted spawning strategies, where $0+$ fish are produced over an extended period, often into mid-summer, but with the trade-off being a shorter growth season. The spawning strategies of cypriniform fish were explored in the River Teme, a spate river in Western England, which has non-indigenous European barbel Barbus barbus present. Sampling 0+ fish in spring and summer and across three spawning periods, B. barbus, chub Squalius cephalus and minnow Phoxinus phoxinus always revealed multiple spawning events, with $0+$ fish of $<20 \mathrm{~mm}$ present in samples collected from June to August. Fish below $20 \mathrm{~mm}$ in August
\end{abstract}

Handling editor: Pauliina Louhi

Electronic supplementary material The online version of this article (https://doi.org/10.1007/s10750-020-04394-9) contains supplementary material, which is available to authorized users.

C. Gutmann Roberts $(\bowtie) \cdot J$. R. Britton

Department of Life and Environmental Sciences, Faculty of Science and Technology, Institute of Aquatic Sciences, Bournemouth University, Poole, Dorset BH12 5BB, UK e-mail: cgutmannroberts@bournemouth.ac.uk remained relatively small by the end of their growth season (October). For dace Leuciscus leuciscus, only single spawning events were evident, but with $0+$ dace always being relatively large. Therefore, multiple spawning appears to be a common strategy that provides resilience in $0+$ fish against stochastic mortality events in lowland rivers.

Keywords Spawning strategies - Invasion biology · Recruitment $\cdot$ Cypriniform · Barbus

\section{Introduction}

In temperate lowland rivers, larval and juvenile fish in their first year of life ('0+') may face episodic flood events that can be deleterious to their cohorts, especially in early summer when individuals are still in early developmental stages (Nunn et al., 2002, 2007a, b). Early developmental stages have not yet developed all fins and muscle structures to withstand flow, and in channelised rivers, seeking slackwaters may not be possible (Bolland et al. 2015). The probability of over-winter survival and recruitment of $0+$ fishes can also be positively correlated to their body lengths at the end of their first growth season (Kirjasniemi \& Valtonen, 1997; Mills \& Mann, 1985; Nunn et al., 2003). 
Spawning strategies of temperate riverine cypriniform fishes vary by species (Vila-Gispert, 2002), but where each strategy is assumed to maximise the survival rates of the $0+$ fish to facilitate larger numbers to survive their first year of life and subsequently recruit (Beardsley \& Britton, 2012a). In species such as dace Leuciscus leuciscus (Linnaeus 1758), spawning can be a single event, usually in early spring and when no other cypriniforms are reproducing (Gutmann Roberts, 2018). This maximises the access of adults to spawning substrates as well as ensuring the $0+$ fish then have an extended growth season that facilitates individual fish to attain relatively large body lengths (e.g. $>50 \mathrm{~mm}$ ) that should increase their probability of surviving the over-wintering period (Mann, 1974; Nunn et al., 2002; Beardsley \& Britton, 2012b). Accessing favourable spawning habitats is enhanced by their relatively large spawning migrations where individuals often move upstream and into tributaries (Clough \& Beaumont 1998; Kottelat \& Freyhof 2007). This strategy, however, also means that a stochastic event in early summer (e.g. a flood) could result in high rates of mortality and/ or downstream displacement (Nunn et al., 2003, 2007a). An alternative strategy is the use of fractional or batch spawning events (hereafter referred to as 'multiple spawning') (Gutmann Roberts, 2018). Utilised by species such as chub Squalius cephalus (Linnaeus 1758), multiple spawning strategies appear to involve a trade-off between prolonged spawning efforts in the adult fish (that can potentially extent over two months) versus a reduced probability of the entire cohort being exposed to the same level of mortality risk from a flood event (Mann, 1976; Nunn et al., 2002, 2007a). In the $0+$ fish, there is then the potential for a trade-off between their higher survival rates in the growth season versus their likelihood of achieving low body sizes at the end of that season (Bolland et al., 2007). This can potentially limit the over-winter survival rates of the smaller individuals that were produced relatively later in the summer (Nunn et al., 2007a, b).

In the rivers of eastern England, the fish communities are generally relatively diverse due to their previous connectivity with the Rhine-Danube systems following the last glacial period (Wheeler \& Jordan, 1990). Conversely, rivers in western England are of lower diversity and so, in attempts to diversify angling opportunities, some non-indigenous species have been introduced, such as European barbel Barbus barbus (Linnaeus 1758) (Wheeler \& Jordan, 1990; Antognazza et al., 2016). In river basins including the Wye and Severn, these introductions have been successful, with non-indigenous $B$. barbus establishing abundant populations (Amat-Trigo et al., 2017), despite the propensity of these rivers to flood regularly (Marriot, 1992) that could inhibit the ability of introduced fish to establish populations (Gutmann Roberts, 2018). Indeed, $B$. barbus is invasive in many other European rivers following introductions to enhance angling that have expanded their natural range (Kotlik \& Berrebi, 2001; Meraner et al., 2013; Zaccara et al., 2019). Nevertheless, there is a considerable knowledge gap on how their spawning strategies in their non-indigenous range influence their $0+$ fish cohorts and how these potentially influence their invasion success (Gutmann Roberts, 2018). This knowledge gap is important, as hypotheses on the establishment probability of introduced species include the 'pre-adaptation hypothesis', which suggests when introduced fishes share similar ecological traits and behaviours with native fishes, they ought to benefit through, for example, a similar ability to acquire resources (Duncan \& Williams, 2002; Ricciardi \& Mottiar, 2006; Buoro et al., 2016; Gutmann Roberts, 2018). Moreover, if this strategy as per that used by the introduced species in their native range, then there is minimal requirement for their reproductive traits to adapt to the new conditions (Schlaepfer et al., 2010; van Kleunen et al., 2011; Gutmann Roberts, 2018).

The aim of this study was to evaluate the range of spawning strategies used by both native and nonindigenous cypriniform fishes in a spate river in Western England, the River Teme. This river forms part of the lower River Severn basin and is prone to spates throughout the year (Gutmann Roberts, 2018). The approach used also allowed testing of the preadaptation hypothesis of invasion biology, where the non-indigenous $B$. barbus were used as the model invasive species. The objectives were to: (1) analyse temporal patterns in the lengths of $0+$ cypriniform fishes and length at end of summer; (2) estimate separate sub-cohorts within a spawning season to determine spawning strategies for each (single vs. multiple spawning); and (3) determine if these spawning strategies, for each species, are consistent between different sites and across different years. 


\section{Materials and methods}

\section{Sampling sites}

The sampling sites $(n=3)$ covered the majority of the $B$. barbus non-indigenous range in the study river (Fig. 1). With negligible off-channel habitat throughout the river, each sampling site consisted of areas of reduced flow rates within the river channel. Site 1 was the furthest upstream, located at Tenbury Wells $\left(52^{\circ} 19^{\prime} \mathrm{N},-2^{\circ} 24^{\prime} \mathrm{W}\right)$ (Fig. 1), where the wetted width of the channel was 26 metres $(07 / 10 / 15)$. The sampled area was located immediately downstream of a road bridge at the downstream end of a large gravel island, near to the right-hand bank. This site is in an urbanised area with little agriculture directly nearby, with a public footpath running along the right-hand bank. Riparian vegetation included overhanging trees (Salix spp.). Within the river, there was minimal instream vegetation, with the river generally running over gravel at depths of $<1 \mathrm{~m}$. The sampling area comprised an area of minimal/ negligible flow, close to the right-hand bank (Gutmann Roberts, 2018). Site 2 was located at Knightwick $\left(52^{\circ} 12^{\prime} \mathrm{N},-2^{\circ} 23^{\prime} \mathrm{W}\right)$ (Fig. 1), where the wetted width was $27 \mathrm{~m}(07 / 10 / 15)$. Sampling was from the right-hand bank, with samples taken either at the downstream end of an exposed gravel beach, or upstream of the gravel beach, in shallow water of a maximum depth of $1 \mathrm{~m}$. Again, instream vegetation was minimal, with the sampling area comprising relatively slack water over a gravel substrate that was contiguous with a gravel riffle (Gutmann Roberts, 2018). Site 3 was the most downstream site at Powick $\left(52^{\circ} 10^{\prime} \mathrm{N},-2^{\circ} 14^{\prime} \mathrm{W}\right)$ (Fig. 1), where wetted width was $15 \mathrm{~m}(07 / 10 / 15)$, with the sampling area located at the downstream end of a gravel riffle used by spawning B. barbus (Pinder et al., 2015). Sampling was conducted from the lefthand bank in an area of shallow, wadable water. The right-hand bank was steep, incised and suffering erosion with sheep grazing pasture extending up to the river (Gutmann Roberts, 2018). The annual

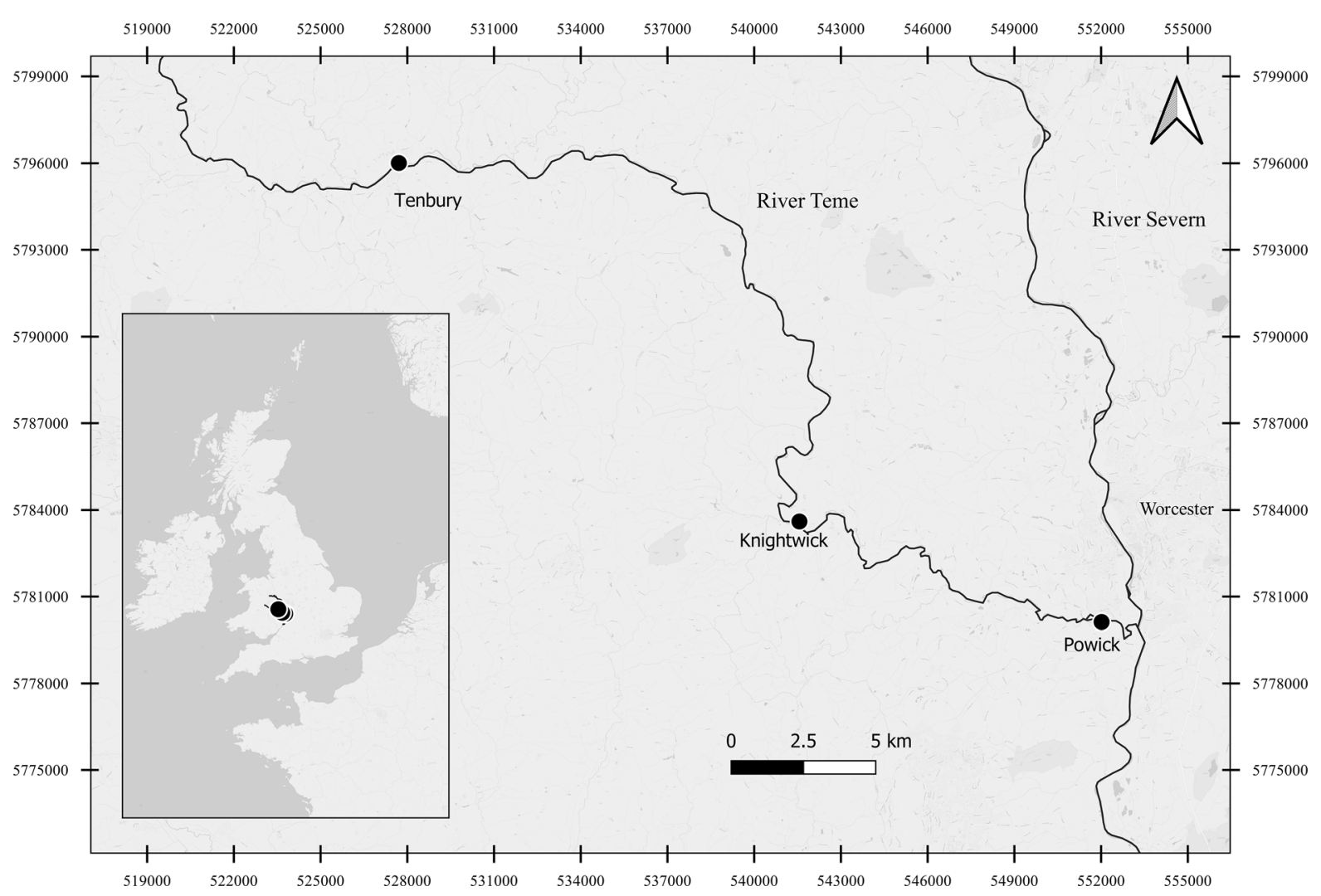

Fig. 1 Map of the three survey Sites (filled circle); 1Tenbury, 2 Knightwick and 3 Powick on the River Teme which flows into the River Severn. Urban areas are shaded grey, with inset showing position of sites and river within the UK 
temperature and flow regime of the River Teme for October 2015 to October 2016 are provided in Gutmann Roberts et al. (2019a); a notable feature of the river is large flood events, especially in winter (Brown et al., 1987), but can also occur throughout the year, including early summer (Gutmann Roberts, 2018).

\section{Sampling methodology}

The sampling method for the $0+$ fish was micro-mesh seine netting (net dimensions: $25 \times 3 \mathrm{~m} ; 2.5 \mathrm{~mm}$ mesh size), which captures more representative samples of larger, juvenile fishes than methods such as point abundance sampling by electric fishing (but with the latter able to provide higher sampling resolution for larval fishes) (Cowx et al., 2001; Nunn et al., 2002, 2003, 2007a, b; Copp, 2010). The net was deployed in appropriate larval and juvenile fish habitats at each site, as identified by areas of habitat off the main flow of the river, where there was sufficient depth (up to $1 \mathrm{~m}$ ) and cover (including overhanging trees and large stones) to provide refuge for the $0+$ fishes (Gutmann Roberts, 2018). Seine nets were deployed by one person staying stationary at the riverbank holding an end of the net whilst the other person walked with the opposite end of the net in a downstream direction, ensuring the bottom of the net remained on the river bed, with the net was looped round by the person then moving out into the river and upstream before returning to the stationary sampler. The net was then brought into the riverbank whilst keeping the bottom of the net on the river bed (Gutmann Roberts, 2018). In 2015, sampling commenced in early July and concluded in October (Table 1). In 2016, sampling commenced earlier to determine the arrival of larvae in nursery habitats, hence sampling commenced in late May and concluded in October (Table 1). In 2017, sampling commenced in May and continued through to September. The rationale for concluding sampling in September/ October was a series of low catches of cypriniforms in the final samples as the $0+$ fishes utilised alternative, non-accessible habitats, in combination with rising water levels that severely limited safe access to the sampling sites (Gutmann Roberts, 2018). Indeed, by October the few B. barbus and $S$. cephalus that were caught were all juveniles in the final stages of development (scales all over body and all fins fully formed) and thus were likely to be starting to utilise deeper water that was not accessible for sampling by micro-mesh seine netting (Copp, 1992; Bischoff \& Freyhof, 1999).

Following netting, all fish were removed from the net and, where catches were sufficiently high at the species level, sub-samples were taken randomly from the main sample with a small hand net, euthanized (anaesthetic overdose, MS-222) and then preserved in $70 \%$ IMS. They were then kept in chilled conditions (approximately $5^{\circ} \mathrm{C}$ ) until their processing in the laboratory (Gutmann Roberts, 2018).

\section{Data collection and analysis}

In the laboratory, for each sampling date and site, the fish were identified to species (Pinder, 2001) and measured using digital calipers (standard length $\left(\mathrm{L}_{\mathrm{s}}\right)$, nearest $0.1 \mathrm{~mm}$ ). Assessment of these data involved calculating their length distributions in $1 \mathrm{~mm}$ class intervals for B. barbus, S. cephalus, Phoxinus phoxinus (Linnaeus 1758) and L. leuciscus (Gutmann Roberts, 2018). These length distributions were plotted temporally by species and site to identify whether there was the appearance of 'new' fish into the cohort throughout the summer, i.e. whether fish of $<20 \mathrm{~mm}$ were regularly appearing in samples collected in July and August that would suggest multiple spawning activities (Nunn et al. 2002, 2007a).

These length distributions were then used to identify the presence of length modes in the samples per site and to assess their growth through each growth season using modal progression analysis (MPA) (Gutmann Roberts, 2018). This method was used here on the assumption that each mode identified by MPA represented a discrete spawning event and that each mode could be tracked through subsequent samples. For each species, site and sampling date, the length distributions were analysed for MPA by decomposition assessment using Bhattacharya's method in FiSAT (Bhattacharya, 1967; Bolland et al., 2007; Hamidan \& Britton, 2014). This analysis identifies the presence of modes in each length distribution by separating them into a series of normal distributions (King, 2013). For each mode, the output was the number of individuals, their mean length and standard deviation (SD) (Bolland et al., 2007), with modes separated by application of a separation index (SI), calculated as the ratio of the difference between 
Table 1 Micromesh seine net sampling dates at sites on the River Teme and day length based on location of S2 and mean daily river level from Bransford located between sites 2 and 3

\begin{tabular}{|c|c|c|c|c|}
\hline Date & Day length (hours:minutes) & River level (m) & River water temperature ( $\mathrm{C}$ ) & Sites sampled \\
\hline $07 / 07 / 15$ & $16: 33$ & 0.42 & 18.0 & $\mathrm{~S} 1$ \\
\hline $08 / 07 / 15$ & $16: 31$ & 0.42 & 17.8 & $\mathrm{~S} 2, \mathrm{~S} 3$ \\
\hline $23 / 07 / 15$ & $15: 58$ & 0.39 & 17.2 & All sites \\
\hline $04 / 08 / 15$ & $15: 21$ & 0.39 & 17.6 & All sites \\
\hline $20 / 08 / 15$ & $14: 23$ & 0.40 & 16.0 & All sites \\
\hline $08 / 09 / 15$ & $13: 10$ & 0.48 & 13.3 & All sites \\
\hline $22 / 09 / 15$ & $12: 14$ & 0.47 & 13.2 & S3 \\
\hline $05 / 10 / 15$ & $11: 21$ & 0.43 & 11.5 & All sites \\
\hline $24 / 05 / 16$ & 16:09 & 0.62 & 13.9 & All sites \\
\hline $06 / 06 / 16$ & $16: 35$ & 0.52 & 18.1 & All sites \\
\hline $29 / 06 / 16$ & $16: 42$ & 0.61 & 14.5 & All sites \\
\hline $08 / 07 / 16$ & $16: 30$ & 0.58 & 16.3 & $\mathrm{~S} 1, \mathrm{~S} 2$ \\
\hline $13 / 07 / 16$ & $16: 20$ & 0.66 & 15.5 & S3 \\
\hline $25 / 07 / 16$ & $15: 50$ & 0.49 & 18.8 & S3 \\
\hline $28 / 07 / 16$ & $15: 41$ & 0.49 & 17.9 & $\mathrm{~S} 1, \mathrm{~S} 2$ \\
\hline $09 / 08 / 16$ & 15:01 & 0.44 & 17.3 & All sites \\
\hline $25 / 08 / 16$ & $14: 01$ & 0.43 & 18.5 & All sites \\
\hline $30 / 08 / 16$ & $13: 42$ & 0.40 & 17.1 & S3 \\
\hline $12 / 09 / 16$ & $12: 51$ & 0.45 & 15.8 & All sites \\
\hline $01 / 10 / 16$ & $11: 34$ & 0.46 & 13.5 & $\mathrm{~S} 2$ \\
\hline $15 / 05 / 17$ & $15: 43$ & 0.55 & 14.8 & All sites \\
\hline $24 / 05 / 17$ & $16: 08$ & 0.52 & 16.1 & S3 \\
\hline $05 / 06 / 17$ & $16: 33$ & 0.47 & 15.8 & All sites \\
\hline $19 / 06 / 17$ & $16: 46$ & 0.44 & 21.4 & All sites \\
\hline $02 / 07 / 17$ & $16: 39$ & 0.42 & 17.7 & All sites \\
\hline $26 / 07 / 17$ & $15: 47$ & 0.41 & 18.3 & All sites \\
\hline 08/08/17 & $15: 05$ & 0.40 & 17.2 & All sites \\
\hline $22 / 08 / 17$ & $14: 14$ & 0.52 & 20.2 & All sites \\
\hline $06 / 09 / 17$ & $13: 15$ & 0.41 & 22.5 & All sites \\
\hline
\end{tabular}

from riverlevels.uk and mean daily water temperature from S2 Environment Agency data 


\section{Results}

Overview of $0+$ fish samples

The cypriniform fish samples from Sites 1 and 2 were dominated by $P$. phoxinus, with $S$. cephalus and $B$. barbus also prominent (Supplementary Material Tables S1 to S3). Other fish species occasionally present in samples but at numbers insufficient for further analyses included stone loach Barbatula barbatula (Linnaeus 1758), bullhead Cottus gobio (Linnaeus 1758), gudgeon Gobio gobio (Linnaeus 1758), and three-spined stickleback Gasterosteus aculeatus (Linnaeus 1758). The species composition of samples from Site 3 were similar to Sites 1 and 2, but with L. leuciscus also present (Tables S1 to S3).

\section{Barbus barbus}

In 2015 , the lengths of the $0+B$. barbus in samples ranged between 13 and $37 \mathrm{~mm}$ across the three sites. Fish of the smallest SLs were recorded in July and fish present $>30 \mathrm{~mm}$ were present at all sites in August samples (Fig. S1). Similarly, in 2016, the length range of $0+B$. barbus was 12 to $37 \mathrm{~mm}$, but with no $B$. barbus in samples until 29/06/16 (Fig. S2). In 2017, sampling commenced in May, with $0+B$. barbus first detected on 05/06/17 (Fig. 2).

In 2015, a relatively large size range of $0+B$. barbus was present in each sample, with the largest length range in the 20/08/15 sample (18 mm; Fig. S1). Length frequency distributions revealed fish of $<$ $15 \mathrm{~mm}$ were still appearing in samples collected in August, with MPA consistently identifying three or four modes in the cohorts over the sampling period and in the sites where the SI exceeded 2.0 (Figs. S1, S3). In 2016, B. barbus of 11 to $12 \mathrm{~mm}$ were in samples collected on 28/07/16, and with fish of 9 to $12 \mathrm{~mm}$ also present in samples collected on 09/08/16 when other individuals were present to lengths $>30 \mathrm{~mm}$ (Fig. S2). Modal progression analysis on the 2016 samples for Site 2 consistently revealed three modes in the cohorts (Fig. S4). In 2017, up to five modes were detected at all three sites, with the majority able to tracked across the sampling period (Fig. 3).
Fig. 2 Standard length $\left(\mathrm{L}_{\mathrm{S}} \mathrm{mm}\right)$ distributions of $0+$ Barbus barbus at Site 1, 2 and 3, River Teme 2017. Note differences in values on the $Y$ axis for comparative purposes

\section{Squalius cephalus}

In 2015, 0+ S. cephalus were present in all samples from all sites and at lengths of 13 to $37 \mathrm{~mm}$ (Fig. S5), with fish of $<20 \mathrm{~mm}$ were always present in samples until late August when fish $>30 \mathrm{~mm}$ were also present (Fig. S5). 0+ S. cephalus were in always samples from early June in 2016 and 2017 (Fig. 4; S6).

Similar to $B$. barbus, there was considerable variability in the $S$. cephalus size ranges per sample, providing evidence that there were extended spawning periods in each year (Figs. S5, S6 and 4). MPA was also able to consistently identify and track up to five modes through the cohorts (Figs. S7, S8 and 5); for example, fish of $<15 \mathrm{~mm}$ were present in samples collected from S1 in 2015 between early July and late August (Fig. S7).

\section{Phoxinus phoxinus}

For $0+P$. phoxinus, their lengths in samples varied between 7 and $50 \mathrm{~mm}$ (Fig. 6, S9, S10), although fish present in May samples of $>27 \mathrm{~mm}$ were considered to be age $1+$ and were not included in subsequent analyses. In all years, smaller fish $(<20 \mathrm{~mm})$ were apparent in samples collected throughout the summer, and even in October, although fish $<10 \mathrm{~mm}$ were generally only present in May to early August (Figs. S9, S10 and 6). As up to six modes could be tracked through the growth season, multiple spawning events were apparent in all sites and years (Fig.s 7, S11, S12).

\section{Leuciscus leuciscus}

The only site where L. leuciscus were sampled consistently was S3, where fish of $<20 \mathrm{~mm}$ were never present in samples collected after $1^{\text {st }}$ July of each year, suggesting there was a discrete annual spawning period relatively early in spring, although the length range of the cohorts was relatively large by October 2015 (32 to $50 \mathrm{~mm}$ ) (Figs. 8, 9, S13, S14). In 2016, 0+ L. leuciscus ranged from 18 to $43 \mathrm{~mm}$, with $0+$ fish in samples as early as 26/06/16 (Fig. S14). In 2017, 
S1
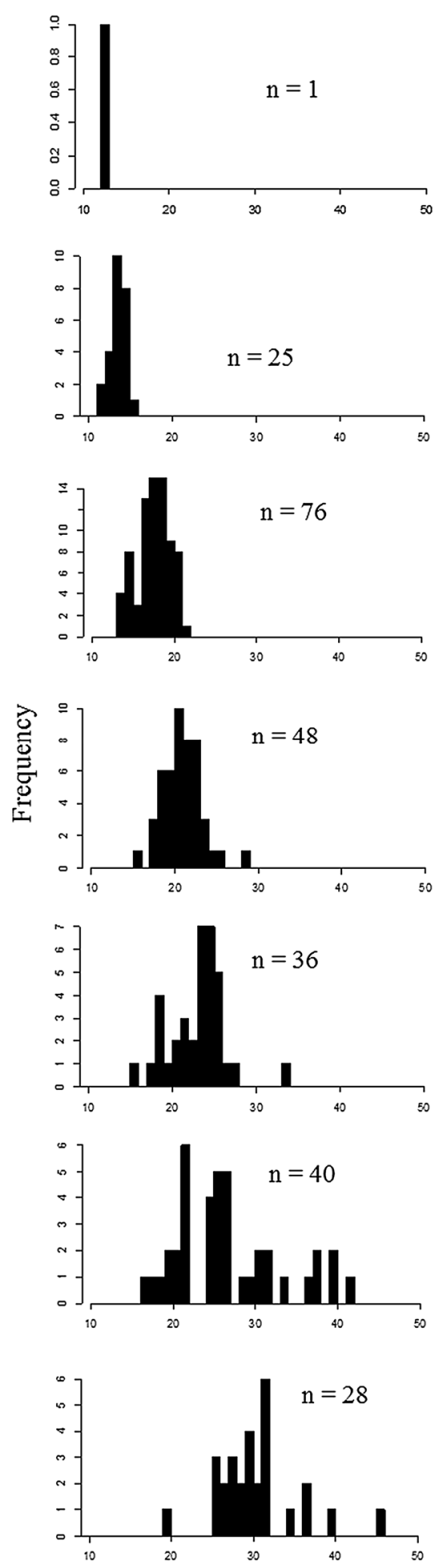

S2
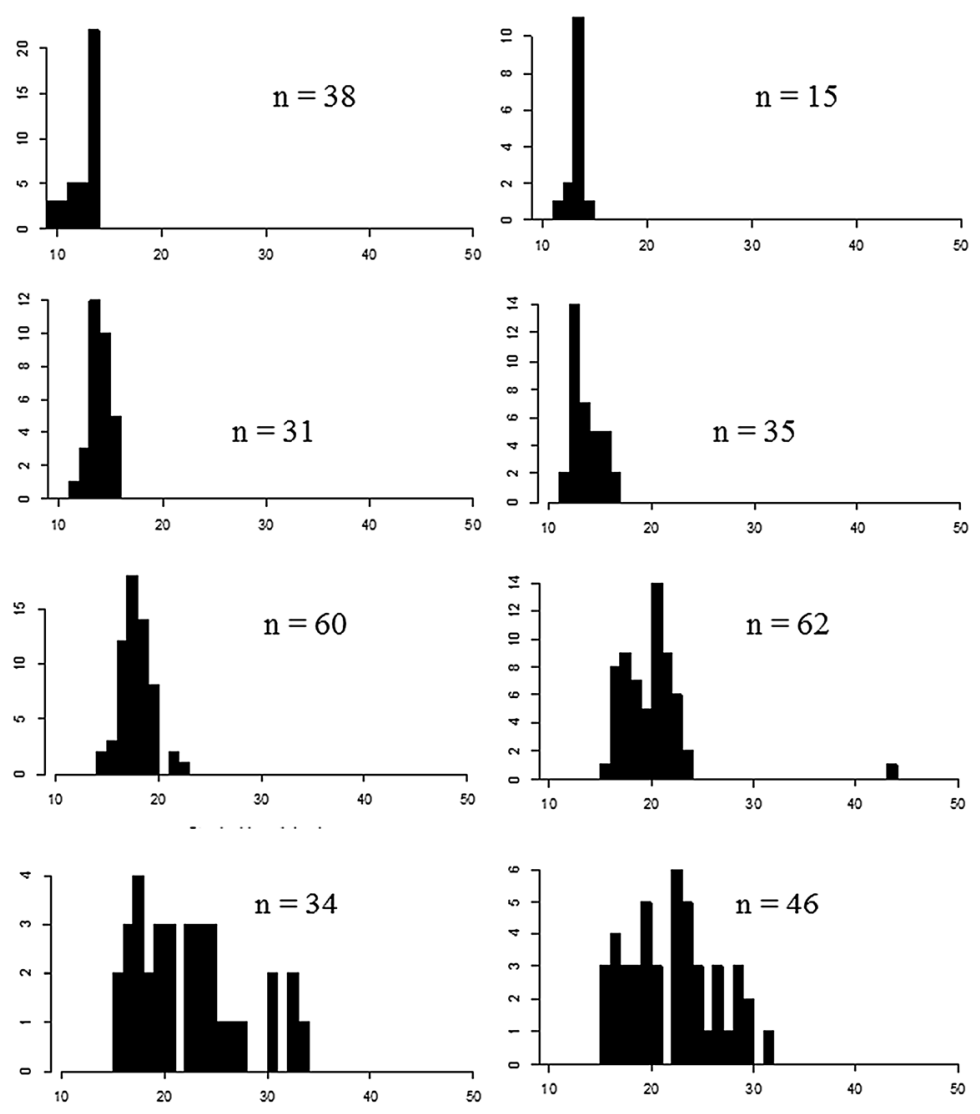

$\frac{8}{8}$
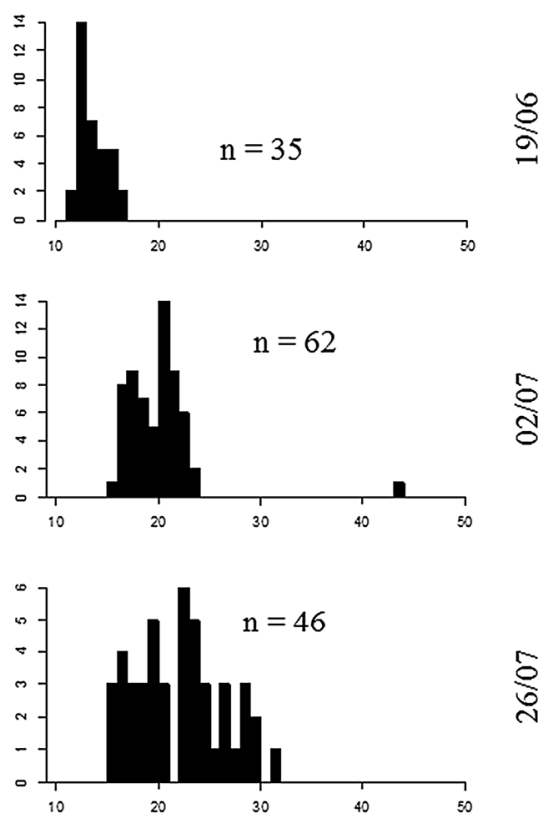

ริ)
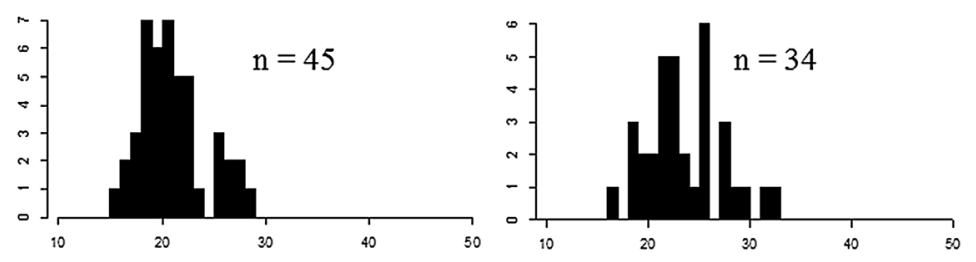

$\stackrel{\infty}{\stackrel{\infty}{\circ}}$
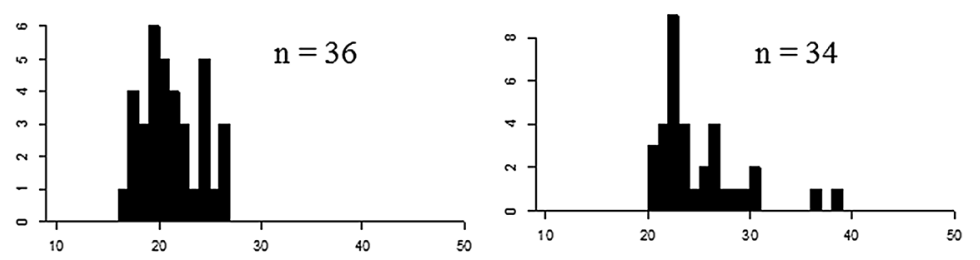

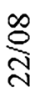

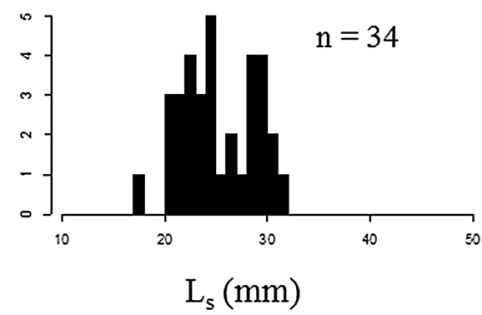
 
sample sizes were reduced from previous years, but the fish maintained their pattern of a single spawning event (Figs. 8 and 9).

\section{Discussion}

There was strong evidence that the majority of the cypriniform fishes in the River Teme had extended
Fig. 4 Standard length $\left(\mathrm{L}_{\mathrm{S}} \mathrm{mm}\right)$ distributions of $0+$ Squalius cephalus at Sites 1, 2 and 3, River Teme 2017. Note differences in values on the $Y$ axis for comparative purposes

spawning periods that suggested a multiple spawning strategy. The native $S$. cephalus and $P$. phoxinus both had new cohorts of $0+$ fish appear within the annual samples at each site, with multiple spawning also

Fig. 3 Mean length (mm, $\pm 95 \% \mathrm{CI}$ ) per mode of Barbus barbus from Site 1-3, River Teme from 2017, as identified by Modal Progression Analysis. The symbols represent each mode
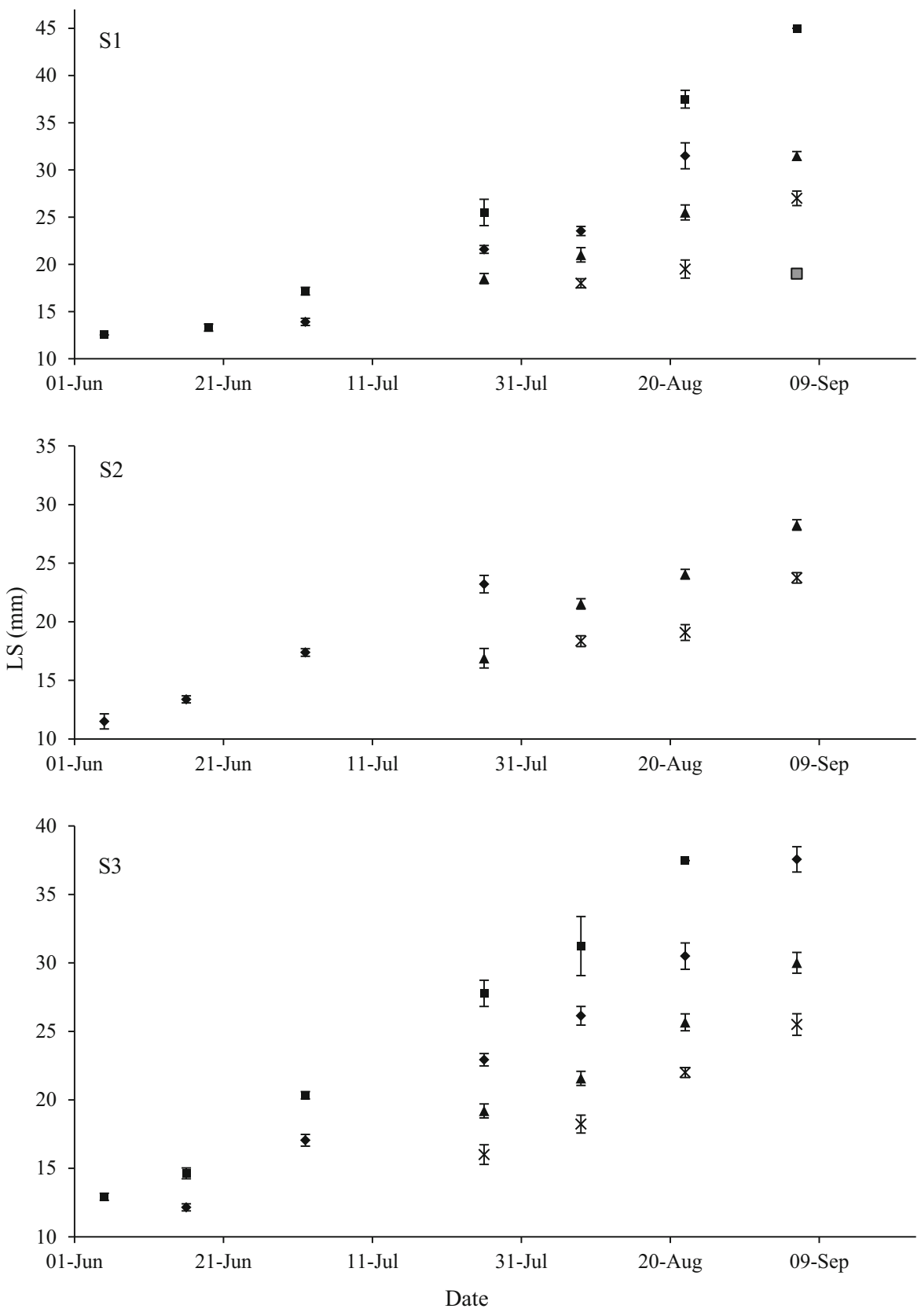
S1
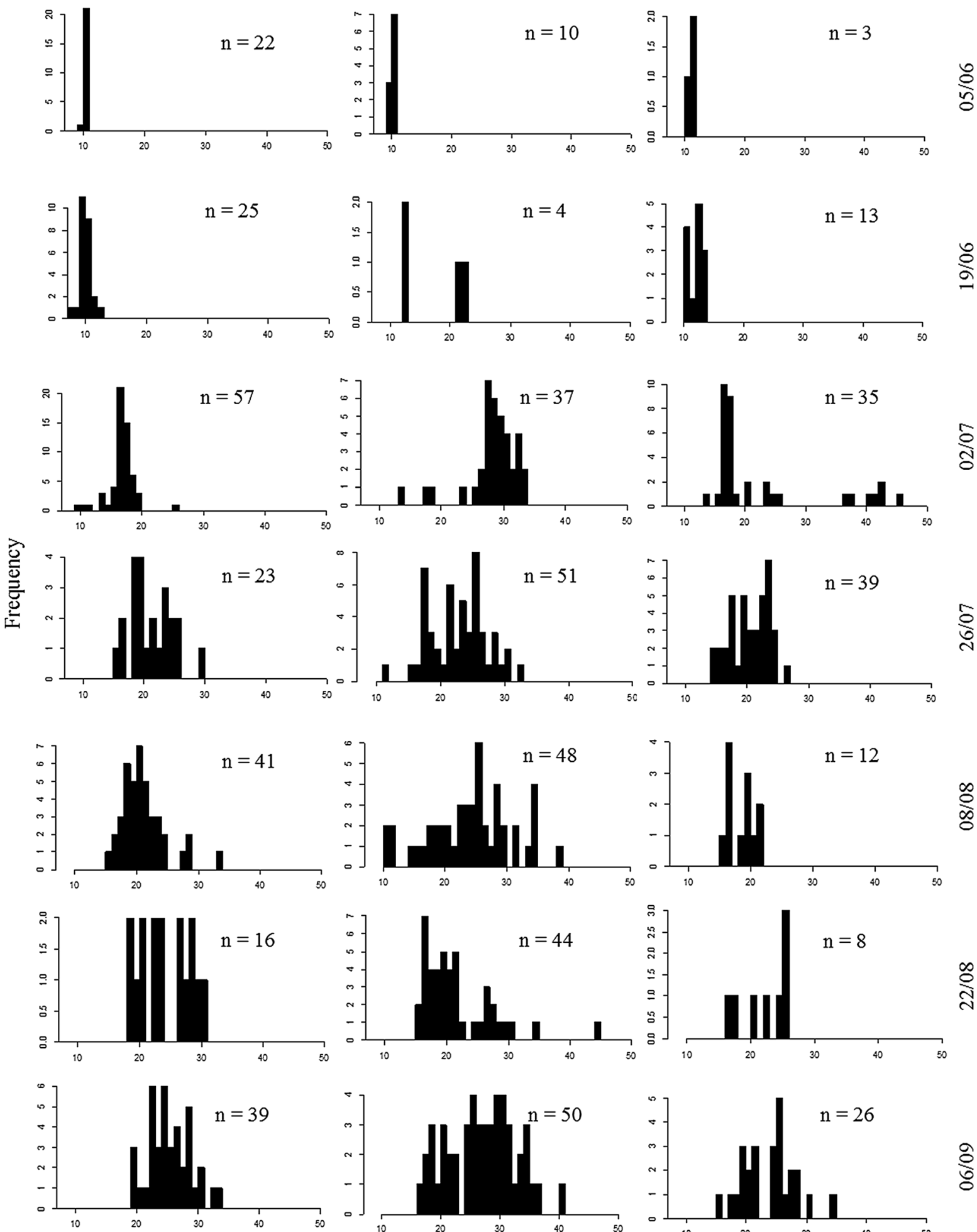

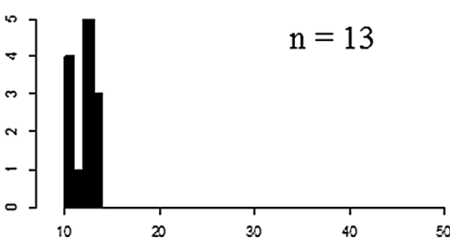

S3

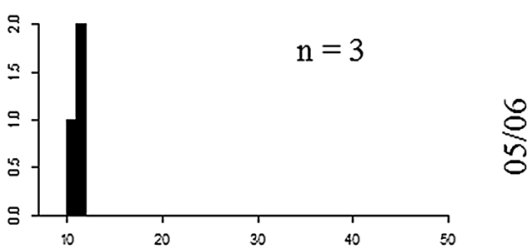

$\stackrel{8}{\circ}$
๙ู่
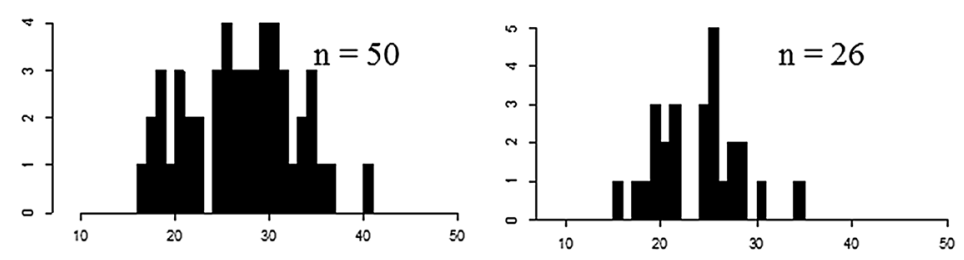

$\stackrel{8}{8}$

$\mathrm{L}_{\mathrm{s}}(\mathrm{mm})$ 
observed in the other populations in England (Nunn et al., 2002, 2007a). Conversely, native L. leuciscus appeared to have a single spawning event each year, which resulted in relatively larger $0+$ fish appearing in samples, at least when compared to the other species. The presence of L. leuciscus solely at Site 3, the most downstream site, is likely due to adult dace residing in the River Severn and migrating into the River Teme tributary for reproduction (Kottelat \& Freyhof 2007). The non-indigenous $B$. barbus also had a multiple
Fig. 6 Standard length $\left(\mathrm{L}_{\mathrm{S}} \mathrm{mm}\right)$ distributions of Phoxinus phoxinus at Sites 1, 2 and 3, River Teme 2017. Note differences in values on the $Y$ axis for comparative purposes

spawning strategy, but where $0+S$. cephalus were present in samples from May, $0+B$. barbus were only present from June onwards.

The introduction of non-indigenous $B$. barbus into the River Severn and their subsequent dispersal into
Fig. 5 Mean length $( \pm$ 95\% CI) per mode of Squalius cephalus from Sites 1, 2 and 3, River Teme from 2017, as identified by Modal Progression Analysis. The symbols represent each mode
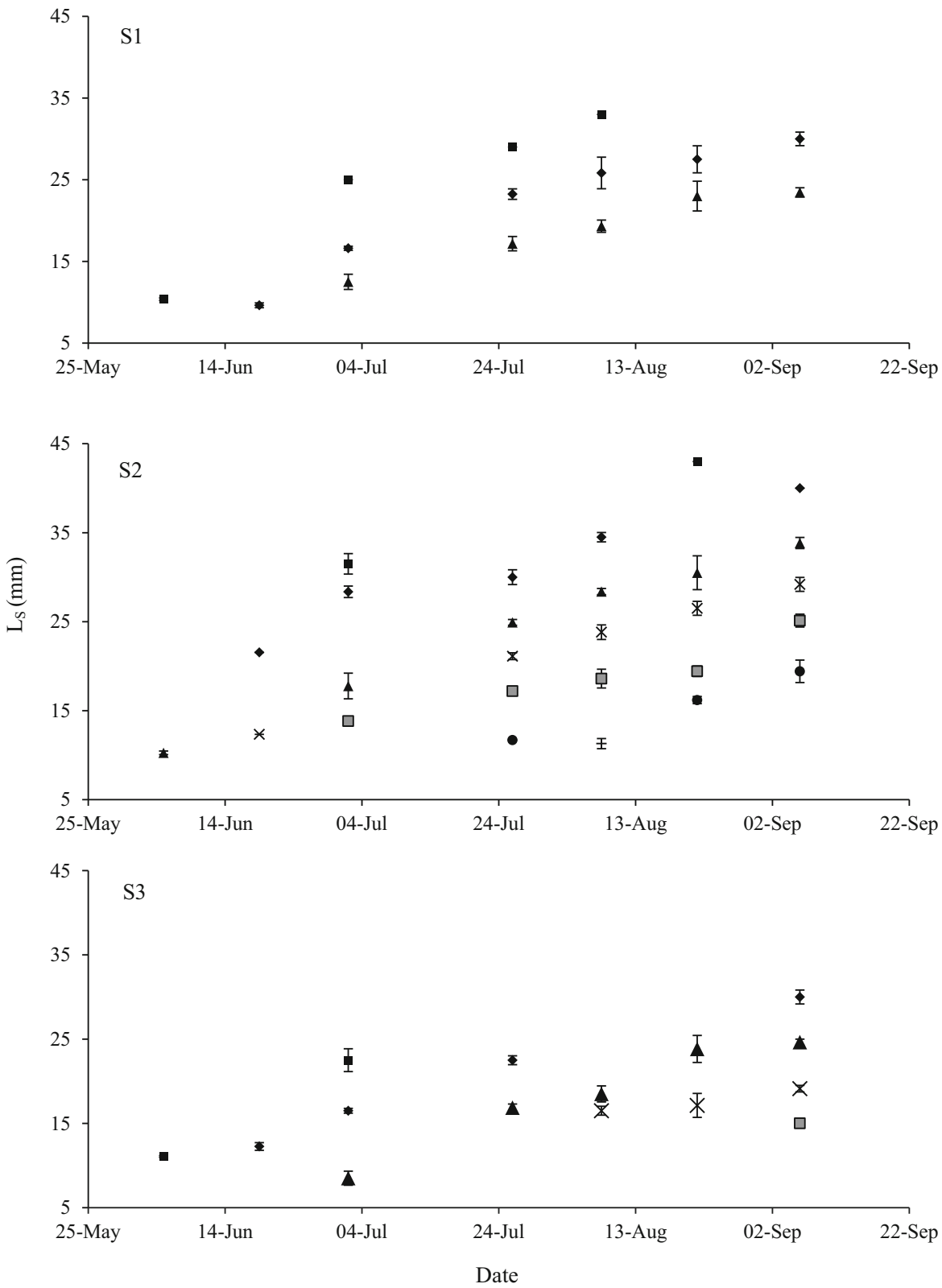
S1
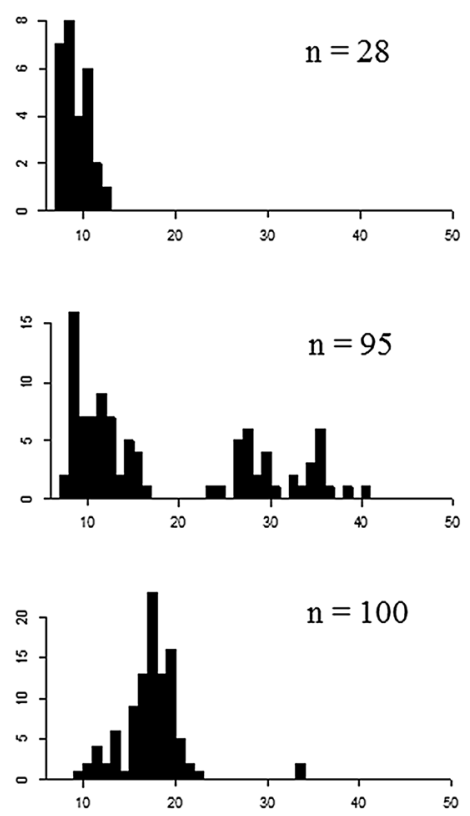

흘
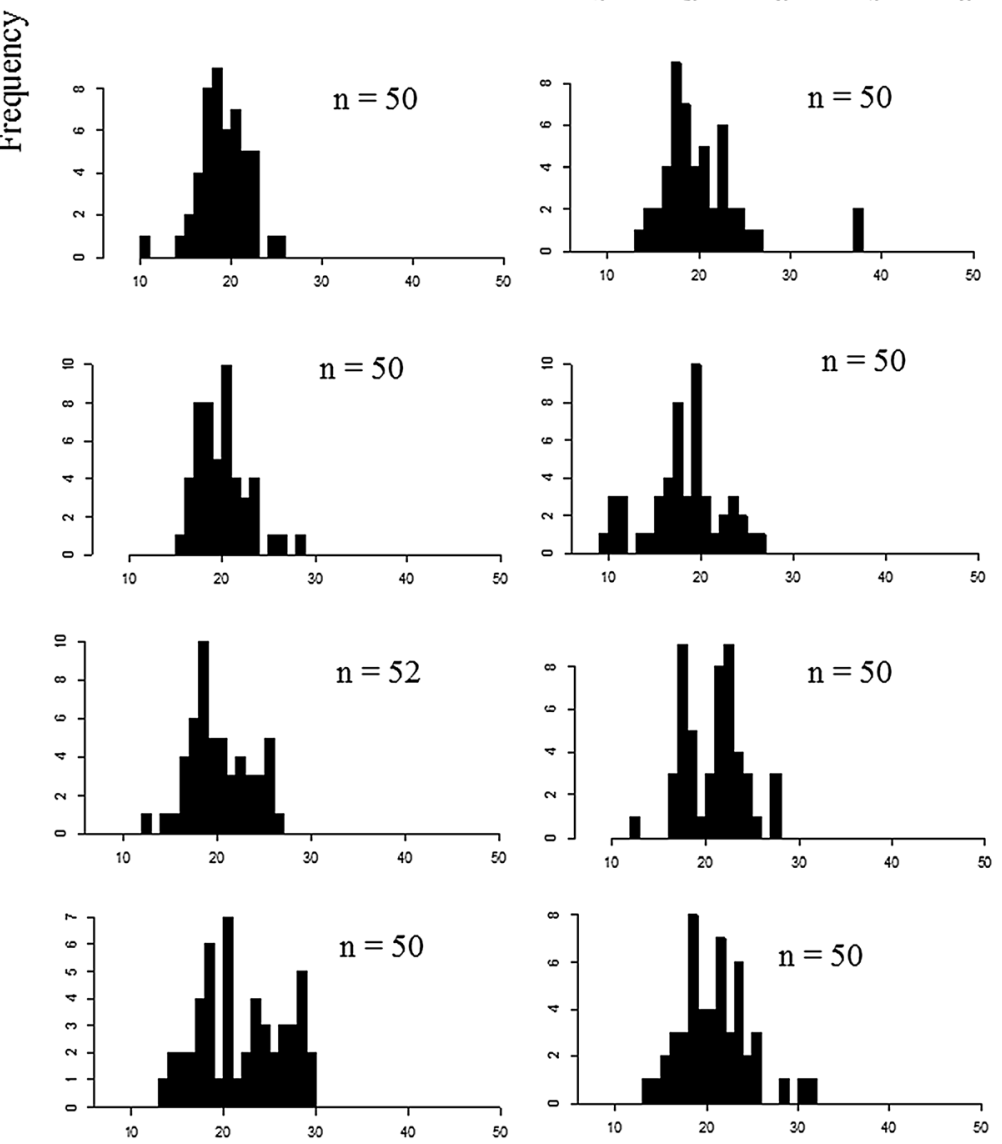

S2
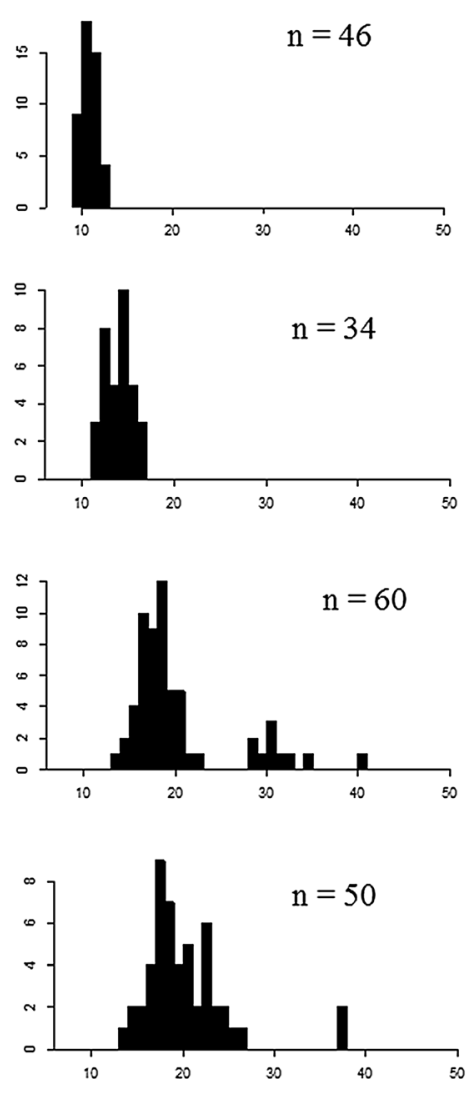

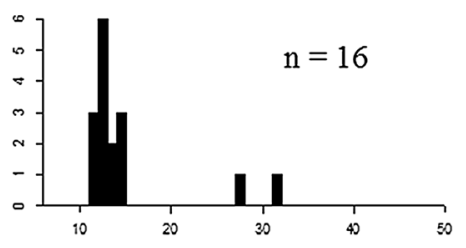

$\stackrel{8}{2}$

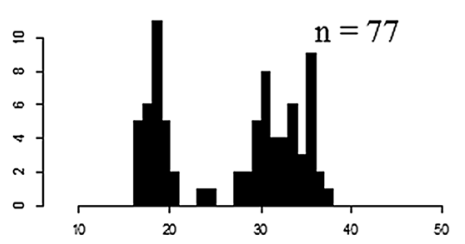

กิ

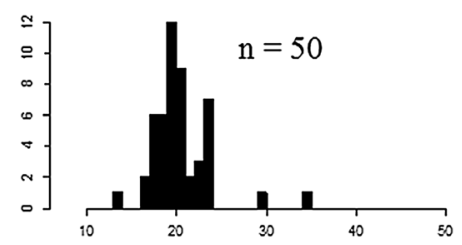

S)

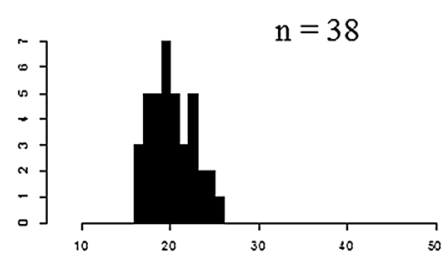

$\stackrel{\infty}{\stackrel{\circ}{\circ}}$

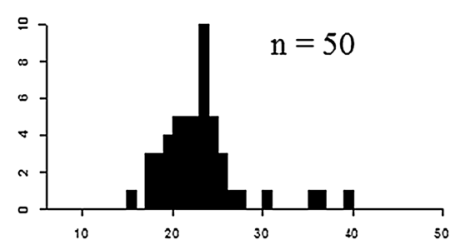

$\stackrel{\text { กิ }}{\stackrel{2}{\circ}}$
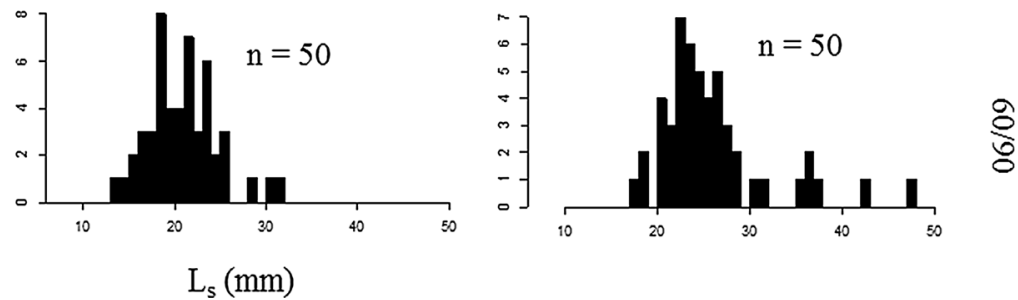
the River Teme thus provided the opportunity, via their spawning strategies, to test the pre-adaptation hypothesis of invasion biology (Ricciardi \& Mottiar, 2006; Schlaepfer et al., 2010; van Kleunen et al., 2011). It was apparent from across the three sampling years, there was a consistent pattern of $B$. barbus having $0+$ fish of $<20 \mathrm{~mm}$ regularly appearing in samples collected between June and late August, suggesting their spawning period extended over several weeks (e.g. between May and July). This multiple spawning was also detected in the native populations of S. cephalus and P. phoxinus. Whilst this multiple spawning strategy could have been mediated in $B$. barbus by plasticity in their reproductive traits, they utilise similar spawning strategies in their native range (Ovidio et al., 2009). For example, individual adult $B$. barbus in the River Ourthe, Belgium, were detected as spawning as least twice per year (Baras, 1995) and in captivity, B. barbus can spawn up to 15 times in 1 year under constant photoperiod and high thermal regimes (Poncin, 1992). Moreover, this apparent pre-adaption is not just limited to their spawning strategies, but also includes their somatic growth rates, as there were no significant differences

Fig. 7 Mean length $( \pm$ 95\% CI) per mode of Phoxinus phoxinus from Sites 1, 2 and 3, River Teme from 2017, as identified by Modal Progression Analysis. The symbols represent each mode
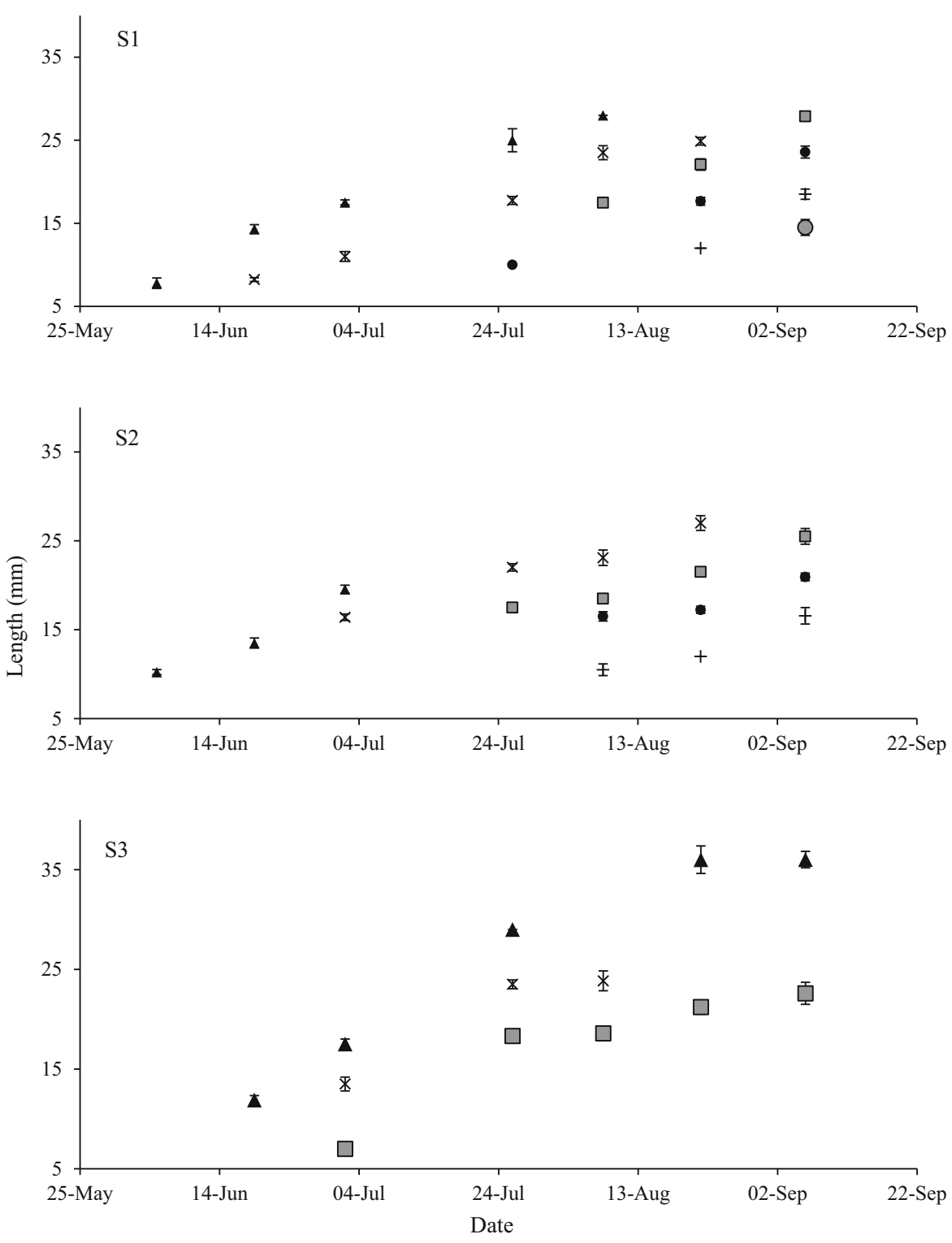

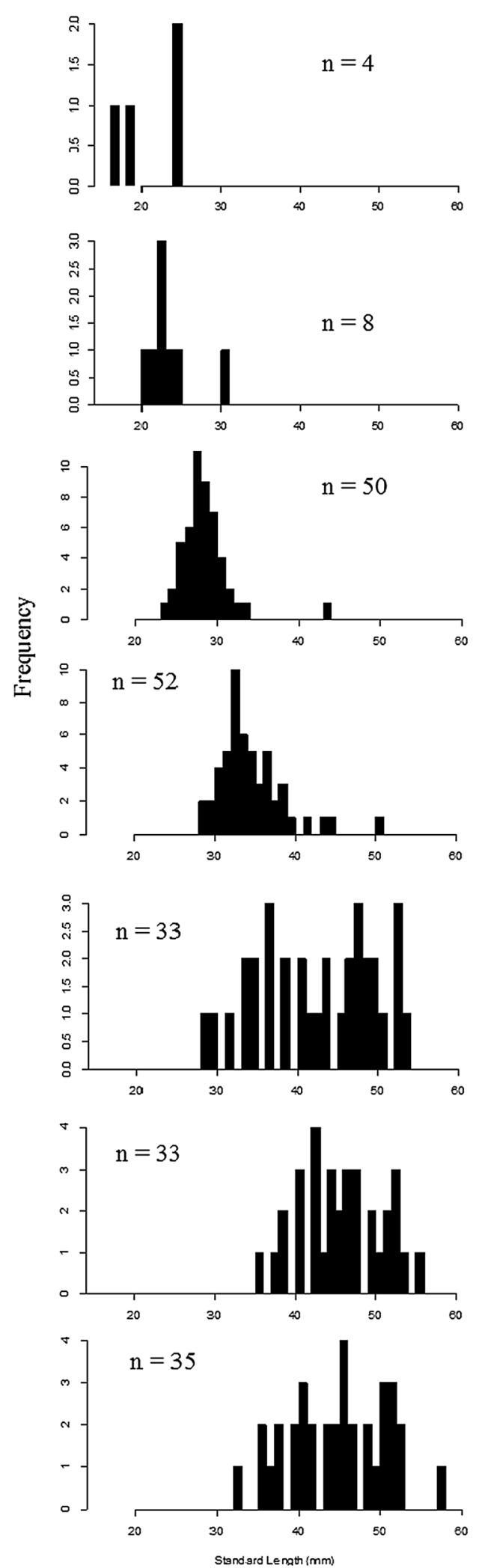

४Fig. 8 Standard length $\left(\mathrm{L}_{\mathrm{S}}\right)$ distributions of Leuciscus leuciscus at Site 3, River Teme 2017. Note variable $y$-axis

$\frac{\wp}{8}$

$\stackrel{\circ}{Ð}$

in adult $B$. barbus growth rates between populations in their British indigenous and non-indigenous ranges (Britton et al., 2012). In entirety, these results suggest that the invasion success of B. barbus in the study river, and potentially elsewhere in their non-indigenous range, is at least partially related to their ability to express their life history traits and behaviours in a similar manner to their indigenous range.

The differences in the spawning strategies between L. leuciscus (single spawning, spring) and the other fishes (multiple spawning, early to mid-summer) at least partially relate to differences in the water temperatures and photoperiod required for initiating their spawning (Gutmann Roberts, 2018). For example, spawning in L. leuciscus usually starts when water temperatures exceed $10^{\circ} \mathrm{C}$ (Kennedy, 1969); in British rivers, this generally occurs between March and April (Mills, 1981) when no other cypriniform fishes are 5 spawning, so they have minimal competition for spawning substrates and then nursery habitats. Consequently, this single spawning event could produce sufficient numbers of $0+$ fish to ensure some survive any subsequent deleterious event, especially if they have achieved a relatively large body lengths by that time. Conversely, the spawning of $B$. barbus, $S$. cephalus and $P$. phoxinus tends to be initiated when water temperatures are higher, usually at least 11 to $12^{\circ} \mathrm{C}$ (Baras, 1995, Koç et al., 2007, Mills, 1987). As these three species all reproduce at similar times (i.e. May to July), and with anadromous fishes, such as shad Alosa spp. and sea lamprey Petromyzon marinus (Linnaeus 1758) also spawning in the river then and on the same spawning locations (Pinder et al., 2015), then there is potential for relatively high competition for spawning substrates and nursery habitats (Gutmann Roberts, 2018; Gutmann Roberts et al., 2019b). Consequently, in addition to increasing the resilience of $0+$ fish to deleterious stochastic events that would subsequently impact recruitment success (Nunn et al., 2002), multiple spawning events could also act to reduce intra- and inter-specific competition for spawning and nursery habitats after June (Gutmann Roberts, 2018). 
Fig. 9 Mean length $( \pm$ $95 \% \mathrm{CI})$ per mode of $0+$ Leuciscus leuciscus from Site 3, River Teme from 2015 (white), 2016 (grey) and 2017 (black) with $0+$ as squares, as identified by Modal Progression Analysis

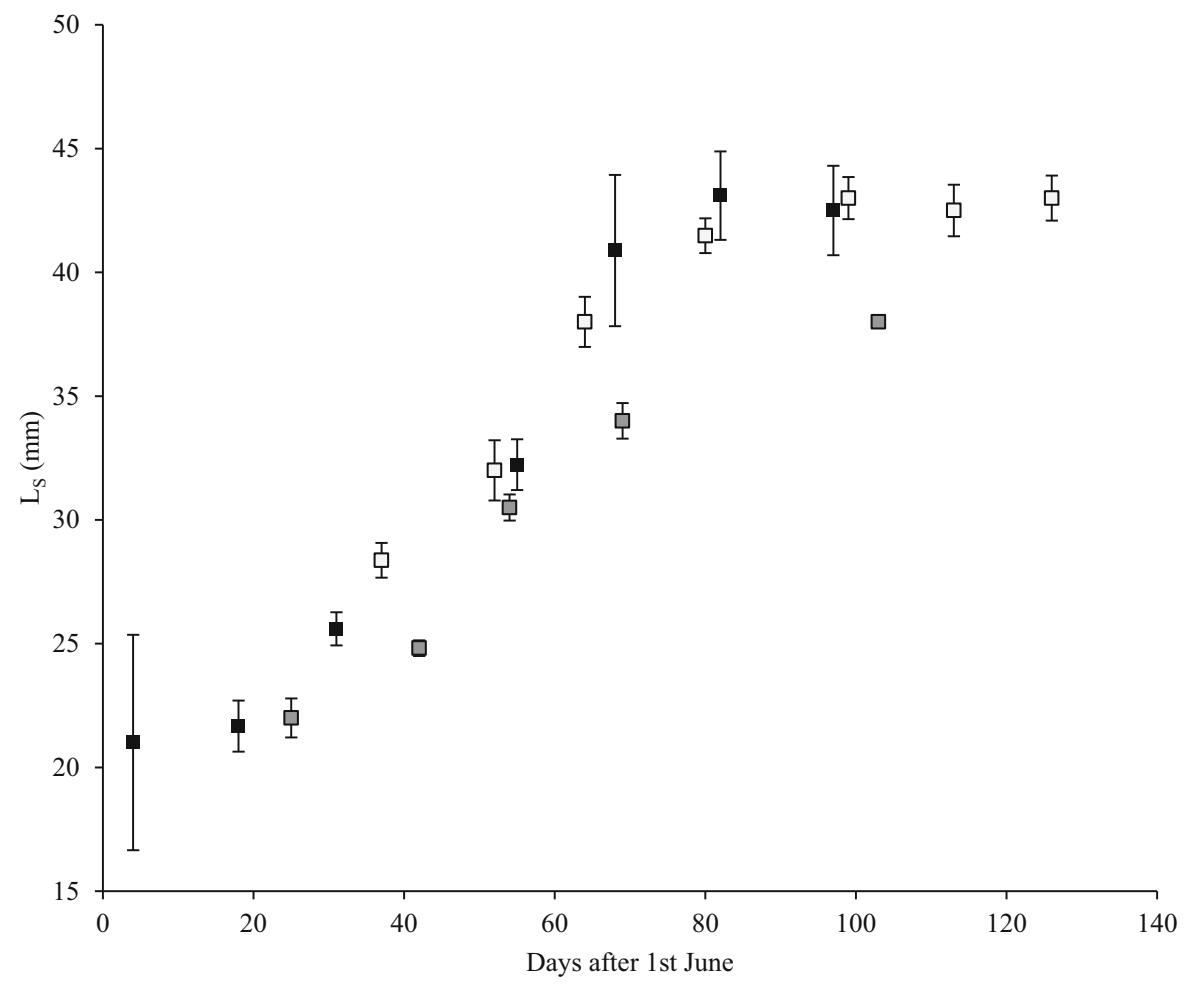

The spawning behaviour of the adult fish was not assessed directly in the study and so the inferences being made from the $0+$ fish samples could not be verified. Nevertheless, the length distributions of the $0+B$. barbus were generally consistent with the production of progeny over prolonged periods (Nunn et al., 2002, 2007a, b), with multiple spawning also strongly suggested in the length data of $S$. cephalus. This reproductive behaviour has also been detected in other S. cephalus populations, including the River Spree, Germany (Fredrich et al., 2003), and the River Rokytna, Czech Republic (Lelek, 1980), where individual adults were observed spawning twice in one spawning season. In England, multiple spawning events have been apparent in $S$. cephalus and $P$. phoxinus from length data from $0+$ fish (Nunn et al., 2007a). Although larger $0+$ B. barbus (> $40 \mathrm{~mm}$ ) were not present in the River Teme samples, this was assumed to be the result of these individuals attaining body sizes that enabled their utilisation of mid-channel habitats of higher flows, as in their native range, individuals can only withstand water velocities in excess of $10 \mathrm{~cm} \mathrm{~s}^{-1}$ when they are of body lengths over $50 \mathrm{~mm}$ (Bischoff and Freyhof, 1999). By late summer, minnow and dace prefer higher water velocities, although minnow have strong preferences for shallow water (Copp 2010), whereas chub prefer deeper waters (Copp 1992). Although there are both similarities and differences in these larval and juvenile fishes in their microhabitat use, the dietary niche of barbel can overlap with these species, although the extent to which this occurs varies spatially (Gutmann Roberts \& Britton 2018). Competition from nonindigenous barbel will depend on densities of fish in comparison with native confamilials and prey availability (Gutmann Roberts, 2018). The densities of larval and juvenile cypriniform fish in similar habitats is also dependent, at least initially, on the fecundity of adults, although the relationship between adult fecundity and spawner density versus the subsequent density of larvae remains uncertain (Gutmann Roberts, 2018; Gutmann Roberts et al., 2019b).

The consequence of the multiple spawning of $B$. barbus and $S$. cephalus in the River Teme was that in samples collected in late summer and autumn when the $0+$ fish growth year was almost complete, some fish were still present in samples at lengths below $20 \mathrm{~mm}$. This indicates that the fish produced relatively late in spawning cycle were unable to compensate for their short growth season through faster growth rates. 
For S. cephalus in other English rivers, this had a lifelong effect on the growth of individuals, where those fish of smaller lengths at the end of their first growth year then remaining relatively small for their age throughout life, but with a tendency to be longer lived than larger, faster growing fish (Bolland et al., 2007). These small $0+$ fish body sizes are also potentially important for recruitment, as length at the end of the first growth season is a significant correlate of recruitment strength in some riverine cypriniforms, including S. cephalus (Nunn et al., 2007a, b). In the River Teme, winter spates can result in river levels increasing by over $4 \mathrm{~m}$ in several hours, with concomitant increases in flows (e.g. to over $60 \mathrm{~m}^{3}$ $\mathrm{s}^{-1}$ ) (Gutmann Roberts, 2018). In conjunction with negligible off-channel refugia and the ability of fish to hold position in flows as a function of their body size (Müller et al., 1996), this suggests that over-winter survival of $0+B$. barbus at lengths below $20 \mathrm{~mm}$ might be limited. This, however, remains speculative in the absence of knowledge of how B. barbus late spawning events translates into lifetime consequences for individuals and cohorts (Gutmann Roberts, 2018). Nevertheless, Nunn et al. (2010) revealed that $0+S$. cephalus in the River Trent were able to survive the winter period at lengths as small as $13 \mathrm{~mm}$.

In conclusion, multiple spawning events were detected here in this non-indigenous $B$. barbus population, with this spawning strategy also utilised by two native fishes, as well as $B$. barbus in their native range. Consequently, it was argued that this aspect of the population's invasion biology had consistency with the pre-adaption hypothesis. The potential implications of these spawning behaviours are increasing the resilience of $0+$ cohorts to deleterious and stochastic events, such as floods, as well as potentially, reducing inter-specific competition for spawning and nursery resources. However, for fish produced later in the summer there is a consequence of these individuals attaining relatively small body sizes at the end of their first growth season that could impact their ability to over-winter.

Open Access This article is licensed under a Creative Commons Attribution 4.0 International License, which permits use, sharing, adaptation, distribution and reproduction in any medium or format, as long as you give appropriate credit to the original author(s) and the source, provide a link to the Creative Commons licence, and indicate if changes were made. The images or other third party material in this article are included in the article's Creative Commons licence, unless indicated otherwise in a credit line to the material. If material is not included in the article's Creative Commons licence and your intended use is not permitted by statutory regulation or exceeds the permitted use, you will need to obtain permission directly from the copyright holder. To view a copy of this licence, visit http://creativecommons.org/licenses/by/4.0/.

\section{References}

Amat-Trigo, F., C. Gutmann Roberts \& J. R. Britton, 2017. Spatial variability in the growth of invasive European barbel Barbus barbus in the River Severn basin, revealed using anglers as citizen scientists. Knowledge \& Managagement of Aquatic Ecosystems. https://doi.org/10.1051/ kmae/2017009.

Antognazza, C. M., D. Andreou, S. Zaccara \& J. R. Britton, 2016. Loss of genetic integrity and biological invasions result from stocking and introductions of Barbus barbus: insights from rivers in England. Ecology and Evolution 6(5): 1280-1292.

Baras, E., 1995. Thermal related variations of seasonal and daily spawning periodicity in Barbus barbus. Journal of Fish Biology 46: 915-917.

Beardsley, H. \& J. R. Britton, 2012a. Recruitment success in a roach Rutilus rutilus population of a hydrologically stable chalk river: relative influences of temperature and flow. Ecology of Freshwater Fish 21(2): 168-171.

Beardsley, H. \& J. R. Britton, 2012b. Contribution of temperature and nutrient loading to growth rate variation of three cyprinid fishes in a lowland river. Aquatic Ecology 46(1): 143-152.

Bhattacharya, G. G., 1967. A simple method of resolution of a distribution into Gaussian components. Biometrics 23: $115-135$.

Bischoff, A. \& J. Freyhoff, 1999. Seasonal shifts in day-time resource use of 0+ barbel, Barbus barbus. Environmental biology of Fishes 56: 199-212.

Bolland, J. D., J. R. Britton \& I. G. Cowx, 2007. Lifetime consequences of variable 0 year group length in riverine populations of chub Leuciscus cephalus (L.). Journal of Fish Biology 71: 1810-1819.

Bolland, J. D., A. D. Nunn, M. C. Lucas \& I. G. Cowx, 2015. The habitat use of young-of-the-year fishes during and after floods of varying timing and magnitude in a constrained lowland river. Ecological Engineering 75: 434-440.

Buoro, M., J. D. Olden \& J. Cucherousset, 2016. Global Salmonidae introductions reveal stronger ecological effects of changing intraspecific compared to interspecific diversity. Ecology Letters 19(11): 1363-1371.

Britton, J. R., G. D. Davies \& J. Pegg, 2012. Spatial variation in the somatic growth rates of European barbel Barbus barbus: a UK perspective. Ecology of Freshwater Fish 22: 21-29.

Brown, A. G., K. J. Gregory \& E. J. Milton, 1987. The use of Landsat multispectral scanner data for the analysis and management of flooding on the River Severn. England. Environmental Management 11(5): 695-701. 
Clough, S. \& W. R. C. Beaumont, 1998. Use of miniature radiotransmitters to track the movements of dace, Leuciscus leuciscus (L.) in the River Frome, Dorset. In Lagardère, J. P., M. L. B. Anras \& G. Claireaux (eds.), Advances in invertebrates and fish telemetry. Developments in hydrobiology, Vol. 130. Springer, Dordrecht.

Copp, G. H., 1992. An empirical model for predicting microhabitat of $0+$ juvenile fishes in a lowland river catchment. Oecologia 91(3): 338-345.

Copp, G. H., 2010. Patterns of diel activity and species richness in young and small fishes of European streams: a review of 20 years of point abundance sampling by electrofishing. Fish and Fisheries 11: 439-460.

Cowx, I. G., A. D. Nunn \& P. Harvey, 2001. Quantitative sampling of 0-group fish populations in large lowland rivers: point abundance sampling by electric fishing versus micromesh seine netting. Archiv fur Hydrobiologie 151(3): 369-382.

Duncan, R. P. \& P. A. Williams, 2002. Ecology: Darwin's naturalization hypothesis challenged. Nature 417: 608-609.

Fredrich, F., S. Ohmann, B. Curio \& F. Kirschbaum, 2003. Spawning migrations of the chub in the River Spree, Germany. Journal of Fish Biology 63: 710-723.

Gutmann Roberts, C., 2018. Population ecology and behaviour of European barbel Barbus barbus, a recreationally important, translocated fish. Doctorate Thesis. Bournemouth University.

Gutmann Roberts, C. \& J. R. Britton, 2018. Quantifying trophic interactions and niche sizes of juvenile fishes in an invaded riverine cyprinid fish community. Ecology of Freshwater fish 27: 976-987.

Gutmann Roberts, C., A. Hindes \& J. R. Britton, 2019a. Factors influencing individual movements and behaviours of invasive European barbel Barbus barbus in a regulated river. Hydrobiologia 830: 213-228.

Gutmann Roberts, C., T. Bašić, J. R. Britton, S. P. Rice \& A. G. Pledger, 2019b. Quantifying the habitat and zoogeomorphic capabilities of spawning European barbel Barbus barbus, a lithophilous cyprinid. River Research and Applications 36(2): 259-279.

Hamidan, N. \& J. R. Britton, 2014. Age and growth rates of the critically endangered fish Garra ghorensis can inform their conservation management. Marine and Freshwater Ecosystems, Aquatic Conservation. https://doi.org/10. 1002/aqc.2449.

Kennedy, M., 1969. Spawning and early development of the dace Leuciscus leuciscus (L.). Journal of Fish Biology 1: 249-259.

King, M., 2013. Fisheries biology, assessment and management. Wiley, New York.

Kirjasniemi, M. \& T. Valtonen, 1997. Size-dependent overwinter mortality of young-of-the-year roach, Rutilius rutilus. Environmental Biology of Fishes 50: 451-456.

Koç, H. T., Z. Erdoḡan, M. Tinkci \& T. Treer, 2007. Age, growth and reproductive characteristics of chub, Leuciscus cephalus (L., 1758) in the İkizcetepeler dam lake (Balikesir), Turkey. Journal of Applied Ichthyology 23: 19-24.

Kotlik, P. \& P. Berrebi, 2001. Phylogeography of the barbel (Barbus barbus) assessed by mitochondrial DNA variation. Molecular Ecology 10: 2177-2185.
Kottelat, M. \& J. Freyhof, 2007. Handbook of European freshwater fishes. Publications Kottelat, Cornol and Freyhof, Berlin: 646.

Lelek, A., 1980. Threatened freshwater fishes of Europe. Council of Europe, Strasbourg: 269.

Mann, R. H. K., 1974. Observations on the age, growth, reproduction and food of the dace, Leuciscus leuciscus (L.), in two rivers in southern England. Journal of Fish Biology 6(3): 237-253.

Mann, R. H. K., 1976. Observations on the age, growth, reproduction and food of the chub, Squalius cephalus (L.) in the River Stour, Dorset. Journal of Fish Biology 8: 265-288.

Marriot, S., 1992. Textural analysis and modelling of a flood deposit: River Severn, U.K. Earth Surface Process and Landforms 17: 687-697.

Meraner, A., A. Venturi, G. F. Ficetola, S. Rossi, A. Candiotto \& A. Gandolfi, 2013. Massive invasion of exotic Barbus barbus and introgressive hybridization with endemic Barbus plebejus in Northern Italy: where, how and why? Molecular Ecology 22: 5295-5312.

Mills, C. A., 1981. The attachment of dace, Leuciscus leuciscus L., eggs to the spawning substratum and the influence of changes in water current on their survival. Journal of Fish Biology 19: 129-134.

Mills, C. A., 1987. The life history of the minnow Phoxinus phoxinus (L.) in a productive stream. Freshwater Biology 17: 53-67.

Mills, C. A. \& R. H. K. Mann, 1985. Environmentally-induced fluctuations in year-class strength and their implications for management. Journal of Fish Biology 27: 209-226.

Müller, U. K. \& J. J. Videler, 1996. Inertia as a 'safe harbour': do fish larvae increase length growth to escape viscous drag? Reviews in Fish Biology and Fisheries 6: 353-360.

Nunn, A. D., I. G. Cowx, P. A. Frear \& J. P. Harvey, 2002. Recruitment patterns of six species of cyprinid fishes in the lower River Trent, England. Ecology of Freshwater Fish 11: 74-84.

Nunn, A. D., I. G. Cowx, P. A. Frear \& J. P. Harvey, 2003. Is water temperature an adequate predictor of recruitment success in cyprinid fish populations in lowland rivers? Freshwater Biology 48(4): 579-588.

Nunn, A. D., J. P. Harvey \& I. G. Cowx, 2007a. Variations in the spawning periodicity of eight fish species in three English lowland rivers over a 6 year period, inferred from 0 -year fish length distributions. Journal of Fish Biology 70: 1254-1267.

Nunn, A. D., J. P. Harvey \& I. G. Cowx, 2007b. The food and feeding relationships of larval and $0+$ year juvenile fishes in lowland rivers and connected waterbodies. Journal of Fish Biology 70: 726-742.

Nunn, A. D., P. A. Frear, M. Lee \& I. G. Cowx, 2010. Is there evidence for a shift in fish growth and recruitment success linked to climate change? Journal of Fish Biology 77: 1780-1792.

Ovidio, M., D. Parkinson, J.-C. Philippart \& E. Baras, 2009. Multiyear homing and fidelity to residence areas by individual barbel (Barbus barbus). Belgian Journal of Zoology 137(2): 183-190.

Pinder, A. C. (ed.), 2001. Keys to larval and juvenile stages of coarse fish from fresh waters in the British Isles. Freshwater Biological Association, Ambleside. 
Pinder A. C., D. Andreou, E. Hardouin, S. Sana, P. Gillingham, \& C. Gutmann Roberts, 2016. Spawning success and population structure of shad (Alosa spp.) in the River Teme, 2015: with supplementary notes on sea lamprey spawning. BUG Report to Natural England.

Poncin, P., 1992. Influence of the daily distribution of light on reproduction in the barbel, Barbus barbus (L.). Journal of Fish Biology 41: 993-997.

Ricciardi, A. \& M. Mottiar, 2006. Does Darwin's naturalization hypothesis explain fish invasions? Biological Invasions 8(6): 1403-1407.

Schlaepfer, D. R., M. Glättli, M. Fischer \& M. Van Kleunen, 2010. A multi-species experiment in their native range indicates pre-adaptation of invasive alien plant species. New Phytologist 185: 1087-1099.

Van Kleunen, M., D. R. Schlaepfer, M. Glaettli \& M. Fischer, 2011. Preadapted for invasiveness: do species traits or their plastic response to shading differ between invasive and non-invasive plant species in their native range? Journal of Biogeography 38: 1294-1304.

Vila-Gispert, A., 2002. Life-history Patterns of 25 species from European Freshwater Fish Communities. Environmental Biology of Fishes 65: 387-400.

Wheeler, A. \& D. R. Jordan, 1990. The status of the barbel, Barbus barbus (L.) (Teleostei, Cyprinidae), in the United Kingdom. Journal of Fish Biology 37: 393-399.

Zaccara, S., S. Quadroni, I. Vanetti, A. Carosi, G. La Porta, G. Crosa, J. R. Britton \& M. Lorenzoni, 2019. Morphologic and genetic variability in the Barbus fishes (Teleostei, Cyprinidae) of Central Italy. Zoologica Scripta 48: 289-301.

Publisher's Note Springer Nature remains neutral with regard to jurisdictional claims in published maps and institutional affiliations. 